\title{
Job Insecurity and Infection Prevention Practices Among Female Domestic Workers After COVID-19 Pandemic in Karachi
}

\author{
Hira Tariq ${ }^{1 *}$, Shiraz Shaikh ${ }^{2}$, Lubna Mazhar ${ }^{3}$, Umm-e-Rubab $^{1}$, Rabia Baloch $^{1}$ and Samina Zaib ${ }^{4}$ \\ ${ }^{1}$ MSPH, Jinnah Sind Medical University, Pakistan \\ ${ }^{2}$ FCPS Community Medicine, Jinnah Sind Medical University, Pakistan
}

${ }^{3}$ MBA, Project Coordinator ICRC, Pakistan

${ }^{4}$ B. Com, Jinnah Sind Medical University, Pakistan

*Corresponding author: Hira Tariq, MSPH, Jinnah Sind Medical University, Pakistan

\section{ARTICLE INFO}

Received: 幽 May 03, 2021

Published: May 10, 2021

Citation: Hira T, Shiraz S, Lubna M, Umm-eRubab, Rabia B, Samina Zaib. Job Insecurity and Infection Prevention Practices Among Female Domestic Workers After COVID-19 Pandemic in Karachi. Biomed J Sci \& Tech Res 35(4)-2021. BJSTR. MS.ID.005734.

Keywords: Female domestic workers; Work Pattern in COVID-19; Health issues; Urban Karachi; Preventive measures

\section{ABSTRACT}

Objective: The objective of the study was to determine the extent of job insecurity and infection prevention practices among domestic workers in different parts of Karachi Pakistan.

Methodology: A cross sectional survey was carried out from July 2020 to November 2020. Snowball sampling was done, and interviews were carried out on phone of 302 female domestic workers consenting to participate. Questionnaire was formed after extensive literature review with major emphasis on infection control measures. Analysis was done in SPSS 20. Logistic regression was applied to associate the preventive measures with socio-demographic factors and work pattern.

Results: Nearly half 144 (47.7\%) were given only partial leave and 64 (21.2\%) were not given leave at all during the lockdown. Less than one third $26.4 \%$ were provided masks by employers and nearly half of the women experienced runny nose $43.7 \%$ and body aches $43.3 \%$ during their work. Significantly higher OR of symptoms was observed in women using same mask in all houses of work 2.74 (1.36-5.52) *** and not maintaining three feet distance $0.04(0.01-0.16)^{* * *}$. Also, as the number of employers increased and the hours of work in the OR of using same mask OR 2.24(1.16-4.31) *, not maintaining three feet distance $0.43(0.20-0.90) *$ and not washing hands also increased.

Conclusion: There is a dire need of recognizing the women domestic working industry and provide them with financial and social support along with protective wear in the current pandemic situation.

\section{Introduction}

The current pandemic of corona virus has taken the world with a surprise and has impacted the economy and quality of life all across the world [1-2]. All the developed and developing economies have been affected with high death tolls and unemployment [3]. Currently, 280 million people are under lockdown restrictions in Europe, 1.3 billion in India and 50-60 million in China [1]. The lockdown especially has had a big impact on the daily wage earners and informally employed individuals [2]. The International Labor Organization has predicted 25 million job losses due to the coronavirus, effecting 2.7 billion workers [3]. On one hand some domestic workers have been fired while others were not allowed to leave home due to travel and gathering restrictions, and the work from home nature of their employers has further increased their workload $[4,5]$.

The only choice left for domestic workers in Europe and US is to either work long tireless hours in their employer's home or to simply lose their jobs. This too is with a lot of responsibility of selfhygiene at their own expenses as they are required to wear masks 
and use sanitizer, which in many cases are not provided by the employers [6]. The situation reported in India and Pakistan which comprises of many part-time as well as full-time domestic workers is even worse, where many domestic workers have lost their jobs in the epidemic and the ones still employed have to walk long distances as there is no public transport, risking their health for the meager money they earn $[7,8]$. Most of the domestic workers are sole earners of their home as noted from previous surveys and reports [9]. Therefore, there is a need to document the current situation of domestic workers in Karachi as the only available information is through print media. The objective of the study was to determine the prevalence of job insecurity and infection prevention practices among domestic workers in different parts of Karachi Pakistan.

\section{Methodology}

This was cross-sectional study conducted on female domestic workers residing in different squatter settlements of Karachi from July 2020 to November 2020. Due to the scattered nature of the domestic workers, their privacy and confidentiality concerns and the pandemic situation of COVID-19 the data was collected through phone calls. All adult female domestic workers above 18 years of age consenting to participate in the study were included. The study started immediately after the lockdown was removed and was completed in four months.

Sample size was calculated using the Open Epi calculator, sample size determination in health studies of world health organization. As there was no statistical data available on the frequency of working pattern and use of preventive measure during COVID-19 of female domestic workers, we used the anticipated frequency to be $50 \%$. At confidence level of $95 \%$ and bound of error of $5 \%$, the sample size came out to be 384 . Due to pandemic situation, we were able to collect data of 302 domestic workers.

Structured questionnaire was used to obtain detailed information on socio-demographics, job characteristics and work patterns after the pandemic (working hours, type of work, nature, salary, job benefits), and infection prevention practices (provision of masks, maintain three feet distance and washing hands at work). Data was collected on phone by female data collectors from medical field in local language. After training, the questionnaire was piloted and revised according to the information and feedback provided by the data collectors. Data was entered twice in Statistical Package for Social Sciences (SPSS) in the form of both numeric codes assigned to the variables and strings form in case of open-ended questions and was also verified by cross-validating it with 10 randomly picked forms from the hard copies. The ethical approval of the proposed study was taken from the Institutional Review Board (IRB).

\section{Data Analysis}

Data was analyzed using SPSS version 21. Descriptive variables were presented as mean and standard deviation or frequency percentages. Comparison of preventive measure with sociodemographic variable and work pattern was done using logistic regression. Odds Ratio was calculated with $95 \%$ confidence interval.

\section{Results}

\section{Job Characteristics During the Pandemic}

The mean age of the study participants was Mean=30, $\mathrm{SD}=8.8$ with more than half of the female domestic workers with no formal education 187 (61.9\%). Majority 203 (67.2\%) were married with an average family size of Mean=7, SD=2.3 and average children Mean=3.2, SD=1.7. More than half 188 (62.3\%) worked for 3 and Above employers/ day with more than two third 217 (71.9\%) working for 5 and Above hours/day. An average salary of female domestic worker was Mean=9556.2, SD=4639.5. More than half worked in DHA and Clifton areas 183 (60.6\%), followed by Ancholi, Garden and Nazimabad 70 (23.2\%) and Gulshan and Gulistan e Johar 49 (16.2\%). Nearly half of the women were granted partial leave $144(47.7 \%)$ and nearly one third were not given leave at all $64(21.2 \%)$ during the lockdown in past two months. More than one third 75 (36.1\%) were called on work every third day followed by $41(19.7 \%)$ those who were called every second day. Nearly one third $60(28.8 \%)$ were not given complete salary if they did not work daily (Table 1 ).

Table 1: Socio-demographic characteristics of the Female domestic Workers $(n=302)$.

\begin{tabular}{|c|c|}
\hline Variables & n (\%) \\
\hline \multicolumn{2}{|l|}{ Age Mean $=30, \mathrm{SD}=8.8$} \\
\hline $18-30$ & $187(61.9 \%)$ \\
\hline 31 and Above & $115(38.1 \%)$ \\
\hline \multicolumn{2}{|l|}{ Level of Education } \\
\hline No formal Education & $187(61.9 \%)$ \\
\hline Primary, Matric and Intermediate & $115(38.1 \%)$ \\
\hline \multicolumn{2}{|l|}{ Marital Status } \\
\hline Single & $85(28.1 \%)$ \\
\hline Married & $203(67.2 \%)$ \\
\hline Divorced and Widow & $14(4.7 \%)$ \\
\hline \multicolumn{2}{|l|}{$\begin{array}{l}\text { Number of Family Members Mean=7, } \\
\qquad S D=2.3\end{array}$} \\
\hline $1-5$ & $79(26.2 \%)$ \\
\hline $6-10$ & $201(66.6 \%)$ \\
\hline 11 and Above & $22(7.3 \%)$ \\
\hline \multicolumn{2}{|l|}{ Number of Children Mean=3.2, SD=1.7 } \\
\hline 0 & $21(7 \%)$ \\
\hline $1-2$ & $162(53.6 \%)$ \\
\hline 3 and Above & $119(39.4 \%)$ \\
\hline \multicolumn{2}{|l|}{ Number of Employers Mean=2.8, $S D=1.1$} \\
\hline $1-2$ & $114(37.7 \%)$ \\
\hline 3 and Above & $188(62.3 \%)$ \\
\hline
\end{tabular}




\begin{tabular}{|c|c|}
\hline Hours of Work Mean=5.95, SD=2.3 & \\
\hline Less than 5 hours & $85(28.1 \%)$ \\
\hline 5 and Above hours & $217(71.9 \%)$ \\
\hline \multicolumn{2}{|l|}{ Monthly Salary Mean=9556.2, SD=4639.5 } \\
\hline Less than 6000 & $91(30.1 \%)$ \\
\hline $6500-14000$ & $148(49 \%)$ \\
\hline 15000 and Above & $63(20.9 \%)$ \\
\hline \multicolumn{2}{|l|}{ Area of Employment } \\
\hline DHA and Clifton & $183(60.6 \%)$ \\
\hline Gulistan e Johar and Gulshan & $49(16.2 \%)$ \\
\hline Ancholi, Gol Garden and Nazimabad & $70(23.2 \%)$ \\
\hline \multicolumn{2}{|l|}{ Leave in the last two months/ Lockdown } \\
\hline No & $64(21.2 \%)$ \\
\hline Yes & $94(31.1 \%)$ \\
\hline Partial & $144(47.7 \%)$ \\
\hline \multicolumn{2}{|l|}{$\begin{array}{l}\text { If Partial/No leave: Frequency of being } \\
\text { called }(n=208)\end{array}$} \\
\hline Daily & $27(13 \%)$ \\
\hline Every 2 days & $41(19.7 \%)$ \\
\hline Every 3 days & $75(36.1 \%)$ \\
\hline Every 4 days & $28(13.5 \%)$ \\
\hline Every 5 days & $17(8.2 \%)$ \\
\hline Every 6 days & $9(4.3 \%)$ \\
\hline Once a week & $5(2.4 \%)$ \\
\hline More than 1 week & $6(2.9 \%)$ \\
\hline \multicolumn{2}{|l|}{ Salary if not called daily $(n=208)$} \\
\hline No & $60(28.8 \%)$ \\
\hline Yes & $148(71.2 \%)$ \\
\hline
\end{tabular}

\section{Infection Prevention Practices During the Pandemic}

Nearly one third 55 (26.4\%) of the female domestic workers started work without washing hands in any of the houses and more than one third 72 (34.6\%) meet their employers by shaking hands. One third $65(31.3 \%)$ were not able to maintain three feet distance at work. More than half of the female domestic workers experienced Covid-19 symptoms 159 (52.6\%) with nearly one third 69 (22.8\%) experiencing cough and nearly half 131 (43.4\%) experiencing body ache and runny nose 132 (43.7\%). Majority 153 (73.6\%) of the participants were not provided masks at work and more than two third $133(63.9 \%)$ of the female domestic workers used the same mask at all places of work with nearly half 95 (45.7\%) using same mask for more than one day (Table 2).

Table 2: Preventive measures and experience of symptoms during work among Female domestic Workers.

\begin{tabular}{|c|c|}
\hline Variables & $\mathbf{n}(\mathbf{\%})$ \\
\hline $\begin{array}{c}\text { Starting the work by washing hands in each } \\
\text { home }(\mathbf{n = 2 0 8})\end{array}$ & \\
\hline Yes & $140(67.2 \%)$ \\
\hline In some houses & $13(6.3 \%)$ \\
\hline
\end{tabular}

\begin{tabular}{|c|c|}
\hline In none of the houses & $55(26.4 \%)$ \\
\hline \multicolumn{2}{|l|}{$\begin{array}{l}\text { Meeting any of the employers by shaking } \\
\text { hands at work }(n=208)\end{array}$} \\
\hline No & 136 (65.4\%) \\
\hline Yes & $72(34.6 \%)$ \\
\hline \multicolumn{2}{|l|}{$\begin{array}{l}\text { Maintaining at-least three feet distance from } \\
\text { all employers while working }(n=208)\end{array}$} \\
\hline No & $65(31.3 \%)$ \\
\hline Yes & $143(68.8 \%)$ \\
\hline \multicolumn{2}{|l|}{$\begin{array}{l}\text { Experienced any of the COVID Symptoms } \\
\qquad(n=302)\end{array}$} \\
\hline No & $143(47.4 \%)$ \\
\hline Yes & $159(52.6 \%)$ \\
\hline \multicolumn{2}{|l|}{ Cough during lockdown $(n=302)$} \\
\hline No & $233(77.2 \%)$ \\
\hline Yes & $69(22.8 \%)$ \\
\hline \multicolumn{2}{|l|}{ Body- Ache during lockdown $(n=302)$} \\
\hline No & $171(56.6 \%)$ \\
\hline Yes & $131(43.4 \%)$ \\
\hline \multicolumn{2}{|l|}{ Runny Nose $(n=302)$} \\
\hline No & $170(56.3 \%)$ \\
\hline Yes & $132(43.7 \%)$ \\
\hline \multicolumn{2}{|l|}{ Fever $(n=302)$} \\
\hline No & $155(84.4 \%)$ \\
\hline Yes & $47(15.6 \%)$ \\
\hline \multicolumn{2}{|l|}{ Provided mask at work $(n=208)$} \\
\hline No & $153(73.6 \%)$ \\
\hline Yes & $55(26.4 \%)$ \\
\hline \multicolumn{2}{|l|}{ Used same mask at all places $(n=208)$} \\
\hline No & $75(36.1 \%)$ \\
\hline Yes & $133(63.9 \%)$ \\
\hline \multicolumn{2}{|l|}{$\begin{array}{l}\text { Used the same mask for more than one day } \\
\qquad(n=208)\end{array}$} \\
\hline No & $113(54.3 \%)$ \\
\hline Yes & $95(45.7 \%)$ \\
\hline
\end{tabular}

(Table 3) shows Logistic regression which was used to compare the preventive measure with different independent variables. As the No of Employers increased the Odds of using same mask also doubled Adjusted OR 2.24(1.16-4.31) * with significant p-value. With increasing Hours of work the odds 1.19 (0.57-2.49) of wearing the same mask at all workplaces also increased but the relation was not significant. Symptoms also increased threefold 2.74 (1.36-5.52) *** when same mask was used at all places with highly significant association.

When maintaining three feet distance was compared a significantly negative association $0.43(0.20-0.90)$ * was seen with less women maintaining three feet distance when working for 3 and above employers. Women who worked for more hours were also less likely to maintain a three feet distance $0.61(0.23-1.64)$ but 
the results were not significant when adjusted. Highly significant negative association 0.04 (0.01-0.16) ${ }^{* * *}$ was observed with symptoms as women who did not maintain distance experienced greater symptoms. Washing hands at work showed decreased in the practice with increased number of employers 0.095 (0.44-2.04) and increased working hours $0.56(0.19-1.63)$ but the results were not significant. However, women experienced greater symptoms who did not was their hands at work and a significant negative association was observed 0.10 (0.03-0.31) *. Age and Education did not have any significant association to any of the outcome variables.

Table 3: Comparison wearing same mask at all places of work, keeping three feet distance and washing hands with socio-demographic factors using Chi-Square analysis $(n=208)$.

\begin{tabular}{|c|c|c|c|c|c|c|}
\hline \multirow[b]{2}{*}{ Variables } & \multicolumn{2}{|c|}{ Using same mask at all places of work } & \multicolumn{2}{|c|}{ Keeping three feet distance } & \multicolumn{2}{|c|}{ Washing hands before starting work } \\
\hline & $\begin{array}{c}\text { Un-Adjusted OR } \\
95 \% \mathrm{CI}\end{array}$ & $\begin{array}{l}\text { Adjusted OR 95\% } \\
\text { CI }\end{array}$ & $\begin{array}{c}\text { Un-Adjusted OR } \\
95 \% \mathrm{CI}\end{array}$ & $\begin{array}{l}\text { Adjusted OR 95\% } \\
\text { CI }\end{array}$ & $\begin{array}{c}\text { Un-Adjusted OR } \\
95 \% \mathrm{CI}\end{array}$ & $\begin{array}{l}\text { Adjusted OR } 95 \% \\
\text { CI }\end{array}$ \\
\hline \multicolumn{7}{|l|}{ Age } \\
\hline $18-30$ & Reference & Reference & Reference & Reference & Reference & Reference \\
\hline 31 and Above & $1.46(0.88-2.86)$ & $1.56(0.75-3.24)$ & $0.58(0.32-1.06)$ & $0.96(0.45-2.04)$ & $0.70(0.37-1.29)$ & $0.97(0.44-2.13)$ \\
\hline \multicolumn{7}{|l|}{ Level of Education } \\
\hline $\begin{array}{l}\text { No formal } \\
\text { Education }\end{array}$ & Reference & Reference & Reference & Reference & Reference & Reference \\
\hline $\begin{array}{l}\text { Primary, Matric } \\
\text { and Intermediate }\end{array}$ & $0.839(0.46-1.50)$ & $1.18(0.58-2.40)$ & $1.27(0.68-2.36)$ & $1.23(0.56-2.68)$ & $1.58(0.81-3.08)$ & $1.23(0.54-2.83)$ \\
\hline \multicolumn{7}{|l|}{ No of Employers } \\
\hline $1-2$ & Reference & Reference & Reference & Reference & Reference & Reference \\
\hline 3 and Above & $2.11(1.17-3.77) *$ & $2.24(1.16-4.31) *$ & $0.46(0.24-0.88) *$ & $0.43(0.20-0.90) *$ & $0.78(0.41-1.49)$ & $0.95(0.44-2.04)$ \\
\hline \multicolumn{7}{|l|}{ Hours of Work } \\
\hline Less than 5 hours & Reference & Reference & Reference & Reference & Reference & Reference \\
\hline 5 and Above Hours & $2.23(1.19-4.18) *$ & $1.19(0.57-2.49)$ & $0.27(0.12-0.62) * *$ & $0.61(0.23-1.64)$ & $0.24(0.09-0.60) * *$ & $0.56(0.19-1.63)$ \\
\hline \multicolumn{7}{|l|}{ Symptoms } \\
\hline No & Reference & Reference & Reference & Reference & Reference & Reference \\
\hline Yes & $\begin{array}{c}3.89(2.14-7.07) \\
* * *\end{array}$ & $\begin{array}{c}2.74(1.36-5.52) \\
* * *\end{array}$ & $\begin{array}{c}0.03(0.01-0.13) \\
* * *\end{array}$ & $\begin{array}{c}0.04(0.01-0.16) \\
* * *\end{array}$ & $\begin{array}{c}0.07(0.02-0.21) \\
* * *\end{array}$ & $0.10(0.03-0.31) *$ \\
\hline
\end{tabular}

${ }^{*} \mathrm{p}<0.05,{ }^{* *} \mathrm{p}<0.01,{ }^{* * *} \mathrm{p}<0.001$

\section{Discussion}

COVID-19 exposes multiple fault lines with the article drawing attention to inequalities observed in women's informal domestic work and how intersections with economic status, power and other factors enables a deeper understanding of the scope of women's care labor at home. This study highlights that majority of female domestic workers involved in work during the pandemic are young, married, with 4 and above children and lack formal education or have a very low literacy rate which makes them highly vulnerable and dependent on informal forms of earning. In general, job conditions were more unfavorable than employee-friendly with very few of the domestic workers given off during the Outbreak lockdown. Majority were given only a partial leave or no leave at all. No extra benefits like clothes or food were also provided to those working during the lockdown. This is consistent with findings from Hong Kong where female domestic workers experienced extra hours of work and hardships as their employers were working from home [5].

According to ILO, COVID-19 threatens the livelihoods of more than 55 million people engaged in domestic work, including 37 million women. Working during the COVID-19 also puts women in a highly contagious environment and as shown by the findings of the study half of the female domestic workers experienced runny nose, body ache and weakness while working for their employers. The study also highlights the other symptoms of COVID-19 like fever, cough also been experienced by women domestic workers. This not only poses a risk for the families of domestic workers but also for the employers they work for as many of them work in more than 3-4 houses on daily basis. These risks have already been highlighted in the United Nations Economic Commission for Latin America and the Caribbean, 2020 [10].

Less than one third of the women were provided masks by their employers highlights the deprivation of these women to basic preventive measures. Majority of the women used the same mask at all places of work and nearly half of them used the same mask for more than one day. This is again in line with the study in Hong Kong and Ethopia where women have expressed the lack of provision of preventive material from employers [5,11].

The association of preventive measures showed that as number of employers and hours of work increased the chances of wearing 
same mask also doubled Adjusted OR 2.24 (1.16-4.31)*. The occurrence of symptoms also increased three times in women using same mask. Similarly, those women working in more houses 0.43 (0.20-0.90)* maintain less distance and also showed significant higher Odds of having symptoms 0.04 (0.01-0.16) ***. Also, when washing hands was compared, we found that women who worked in 3 and above houses and longer working hours was significantly associated with less hand washing and also higher symptoms. All these findings indicate that number of employers has a high influence on the usage of preventive measure and the occurrence of symptoms and is in line with the study in India [7]. The finding again reinforces the guidelines of WHO to prevent COVID-19 and highlights the vulnerability of the Female domestic workers to infection $[10,12]$.

Based on the findings, we propose a few recommendations. First, data that documents female domestic worker's care roles and economic status is essential in understanding the intersecting dimensions to women's care labor both during and after COVID-19. Second, workers in the informal sector will continue to need protection, with explicit attention required to inequities in access to personal protective equipment and work-site safety. Lastly to ensure women's perspectives are addressed, the voices of informal sector especially women should be central to developing short- and long-term responses to COVID-19. This study has a few limitations and is only the first step in the direction of highlighting the situation of female domestic workers during a pandemic situation in Karachi. The sample size could not be achieved as many of the women are poor and have limited access to technology such as mobile phones which was a major hindrance in the collection of data.

\section{Conclusion}

As the pandemic has reshaped the entire economic, social and legal framework of the world. There is a need to recognize the female domestic workers' industry, providing them with social and financial protection along with protection at work so they do not have to risk their health and lives to bread their homes.

\section{ISSN: 2574-1241}

DOI: 10.26717/BJSTR.2021.35.005734

Hira Tariq. Biomed J Sci \& Tech Res

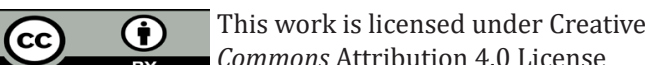

Submission Link: https://biomedres.us/submit-manuscript.php

\section{Acknowledgments}

I acknowledge and express my gratitude to all the female domestic workers who participated in the study.

\section{References}

1. Lippi G, Henry BM, Bovo C, Gomar FS (2020) Health risks and potential remedies during prolonged lockdowns for coronavirus disease 2019 (COVID-19). Diagnosis 7(2): 85-90.

2. Borah A, Das S, Dasgupta A, Deshpande A, Mahajan K, et al. (2020) Covid-19: Are we ready for the long haul?-Part II.

3. (2020) Organization IL, COVID-19: impact could cause equivalent of 195 million job losses, says ILO chief, in UN News.

4. PAO J (2020) Covid-19 puts pressure on HK domestic workers, in Asia Times.

5. Chan A (2020) Hong Kong's Domestic Workers: When 'Stay at Home' Means 'Live at Work', in The Diplomat.

6. Colombi (2020) COVID-19-A social emergency for millions of precarious workers in Europe. 2020 European Federation of Food, Agriculture and Tourism Trade Unions.

7. Dey S (2020) 'Modiji, Please Help Karo': Women Domestic Workers Struggling for Basic Necessities During Covid-19 Lockdown, in News 18 India.

8. Habib S (2020) Domestic workers bear the brunt of coronavirus outbreak, in The News.

9. Tariq H, S Shaikh, M Musharaf (2020) Working conditions and workrelated health issues of female domestic workers in four districts of Karachi. Annals of work exposures and health 64(4): 378-386.

10. Lokot M, A Bhatia (2020) Unequal and Invisible: A Feminist Political Economy Approach to Valuing Women's Care Labor in the COVID-19 Response. Frontiers in Sociology 5: 88 .

11. Amdeselassie T, Emirie G, Gezahegne K, Jones N, Marshall EP, et al (2020) Experiences of vulnerable urban youth under covid-19: the case of domestic workers. Policy brief: COVID-19 Series, Ethiopia, London: Gender and Adolescence: Global Evidence (GAGE).

12. Novel CPERE (2020) The epidemiological characteristics of an outbreak of 2019 novel coronavirus diseases (COVID-19) in China. Zhonghua Liu Xing Bing Xue Za Zhi 41(2): 145-151.

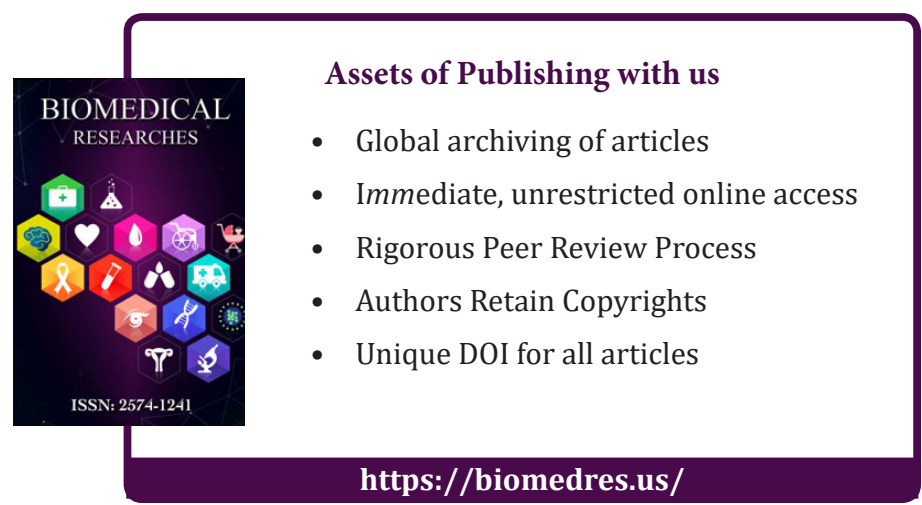

